Article

\title{
Oxidations of Benzhydrazide and Phenylacetic Hydrazide by Hexachloroiridate(IV): Reaction Mechanism and Structure-Reactivity Relationship
}

\author{
Xiaolai Zhang \\ College of Chemistry and Chemical Engineering, Shandong University, Jinan 250014, China; \\ zhangxlai@sdu.edu.cn; Tel.: +86-0531-8839-2606
}

Received: 27 September 2019; Accepted: 9 January 2020; Published: 12 January 2020

\begin{abstract}
Benz(o)hydrazide (BH) is the basic aryl hydrazide; aryl hydrazides have been pursued in the course of drug discovery. Oxidations of $\mathrm{BH}$ and phenylacetic hydrazide (PAH) by hexachloroiridate(IV) $\left(\left[\mathrm{IrCl}_{6}\right]^{2-}\right)$ were investigated by use of stopped-flow spectral, rapid spectral scan, RP-HPLC and NMR spectroscopic techniques. The oxidation reactions followed well-defined second-order kinetics and the observed second-order rate constant $k^{\prime}$ versus $\mathrm{pH}$ profiles were established over a wide $\mathrm{pH}$ range. Product analysis revealed that $\mathrm{BH}$ and $\mathrm{PAH}$ were cleanly oxidized to benzoic acid and phenylacetic acid, respectively. A reaction mechanism was proposed, resembling those suggested previously for the oxidations of isoniazid (INH) and nicotinic hydrazide (NH) by $\left[\mathrm{IrCl}_{6}\right]^{2-}$. Rate constants of the rate-determining steps were evaluated, confirming a huge reactivity span of the protolysis species observed previously. The enolate species of $\mathrm{BH}$ is extremely reactive towards reduction of $\left[\mathrm{IrCl}_{6}\right]^{2-}$. The determined middle-ranged negative values of activation entropies together with rapid scan spectra manifest that an outer-sphere electron transfer is probably taking place in the rate-determining steps. The reactivity of neutral species of hydrazides is clearly not correlated to the corresponding $\mathrm{p} K_{\mathrm{a}}$ values of the hydrazides. On the other hand, a linear correlation, $\log k_{\text {enolate }}=(0.16 \pm 0.07) \mathrm{p} K_{\text {enol }}$ $+(6.1 \pm 0.8)$, is found for the aryl hydrazides studied so far. The big intercept and the small slope of this correlation may pave a way for a rational design of new antioxidants based on aryl hydrazides. The present work also provides the $\mathrm{p} K_{\mathrm{a}}$ values for $\mathrm{BH}$ and $\mathrm{PAH}$ at $25.0^{\circ} \mathrm{C}$ and $1.0 \mathrm{M}$ ionic strength which were not reported before.
\end{abstract}

Keywords: benzhydrazide; phenylacetic hydrazide; hexachloroirridate(IV); oxidation; reaction mechanism; structure-reactivity relationship

\section{Introduction}

Hydrazides are widely employed for manufactures of polymers and glues and utilized as chemical preservers for plants in industry [1,2]. They are potent reagents for synthesis of various oxygen-, nitrogen-, and/or sulfur-containing heterocyclic rings in organic chemistry [1]. Hydrazide scaffold based clinical medicines involve isoniazid (INH), marplan, iproniazid, and indolylglyoxyl hydrazide [2] and INH has been a frontline anti-tubercular drug for a few decades [3-5]. Ascribed to the structural diversity and to the huge success of INH, hydrazides and their derivatives have been a base for new drug discoveries $[2,6-10]$.

Mechanistically, the anti-tubercular action of INH involves its activation by enzymes generating hydrazyl free radical(s) in the activation course [11-14]. The involvement of free radicals may not be surprising since numerous oxidation reactions are taking place in biologically and/or biomedically relevant processes which involve a single electron transfer. $\left[\mathrm{IrCl}_{6}\right]^{2-}$ is a well-known single electron oxidizing agent [15-19] and it has been utilized as a redox probe for acquiring chemical information of 
oxidative stress [20]. In a recent kinetic study of oxidations of INH and its analog nicotinic hydrazide (NH) by $\left[\mathrm{IrCl}_{6}\right]^{2-}[14]$, it was found for the first time that the four protolysis species of INH and NH showed a huge reactivity difference (about $10^{9}$ times) towards reduction of the $\operatorname{Ir}(\mathrm{IV})$ complex and the enolate forms of INH and $\mathrm{NH}$ were extremely reactive. Inspired by this study, we carried out a similar kinetic investigation of the oxidations of benz $(\mathrm{o})$ hydrazide $(\mathrm{BH})$ and phenylacetic hydrazide $(\mathrm{PAH})$; the structures of INH, NH, BH, and PAH are illustrated in Figure S1 in Supplementary Materials (SM). Structurally, BH is the basic aryl hydrazide and has a close proximity to INH. Indeed, BH and its derivatives have been investigated extensively towards discovery of new drugs $[9,10,21,22]$ and catalysts [23]. The oxidation kinetics of $\mathrm{BH}$ by bromate in acidic media catalyzed by V(IV) and $\mathrm{Mn}(\mathrm{II})[24,25]$ and by enzymes $[26,27]$ were reported; but in these studies, the enol/enolate form of BH was not considered.

The aims of this investigation were: (i) to characterize the oxidations of $\mathrm{BH}$ and $\mathrm{PAH}$ by the Ir(IV) complex in a wide $\mathrm{pH}$ range by use of stopped-flow spectral, rapid spectral scan, RP-HPLC and NMR spectroscopic techniques; (ii) to derive the reactivity of the protolysis species of the two hydrazides towards reduction of $\operatorname{Ir}(\mathrm{IV})$; (iii) to verify the exceptional high reactivity of the enolate forms of $\mathrm{BH}$ and $\mathrm{PAH}$; (iv) to compare the kinetic data of $\mathrm{BH}$ with those of $\mathrm{INH}$; and (v) to examine the structure-reactivity relationships.

\section{Results}

\subsection{Spectral Analysis of Reaction Course}

For probing some useful information in the reaction course of $\mathrm{BH}$ with $\left[\mathrm{IrCl}_{6}\right]^{2-}$, rapid scan spectra were recorded on the stopped-flow spectrometer under a set of reaction conditions. The obtained spectra are shown in Figure 1, which are similar to those acquired previously in the oxidations of $\mathrm{INH}$ and hydrazines with $\left[\mathrm{IrCl}_{6}\right]^{2-}[14,28]$. This type of rapid scan spectra renders a few salient features [14,28]: (1) neither a substitution reaction on the $\operatorname{Ir}(\mathrm{IV})$ complex nor a strong association between the $\left[\mathrm{IrCl}_{6}\right]^{2-}$ and $\mathrm{BH}$ before the rate-determining step(s) underwent since the two disappearing bands around 428 and $488 \mathrm{~nm}$ which originate from $\left[\mathrm{IrCl}_{6}\right]^{2-}$ showed no shifts and no new absorption bands emerged. (2) The kinetic traces could be well described by Equation (1) under the pseudo first-order reaction conditions,

$$
A_{\mathrm{t}}=\left(A_{0}-A_{\infty}\right) \exp \left(-k_{\mathrm{obsd}} t\right)+A_{\infty}
$$

where $k_{\mathrm{obsd}}$ stands for pseudo first-order rate constant, and $A_{\mathrm{t}}, A_{0}$, and $A_{\infty}$ represent the absorbances at time $t$, zero, and infinity, respectively. Figure S2 in SM shows good fits of the kinetic traces acquired at 428 and $488 \mathrm{~nm}$. (3) The values of $k_{\text {obsd }}$ obtained at the two wavelengths are identical within experimental errors. These features endow that the oxidation reaction is indeed first-order in $\left[\mathrm{IrCl}_{6}{ }^{2-}\right]$. The same features were also observed for the oxidation of PAH by $\left[\mathrm{IrCl}_{6}\right]^{2-}$. 


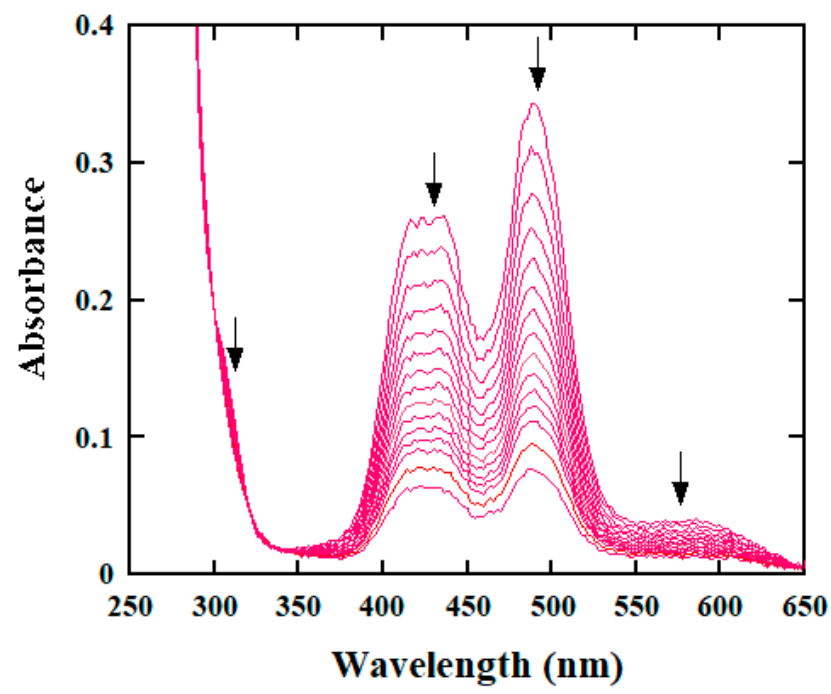

Figure 1. Rapid scan spectra obtained for the oxidation of benz(o)hydrazide $(\mathrm{BH})$ by $\left[\mathrm{IrCl}_{6}\right]^{2-}$ under the reaction conditions: $[\mathrm{Ir}(\mathrm{IV})]=0.20 \mathrm{mM},[\mathrm{BH}]_{\text {tot }}=3.00 \mathrm{mM}$, phosphate buffer of $\mathrm{pH} 5.10, \mu=1.0 \mathrm{M}$ and $25.0^{\circ} \mathrm{C}$. The spectra were acquired at $3,33,63,92,123,152,182,212,242,273,303,332,364,423$, and 500 milliseconds after the start of the reaction.

\subsection{Empirical Rate Law and Kinetic Data Collection}

To find the reaction order in $[\mathrm{BH}]_{\mathrm{tot}} /[\mathrm{PAH}]_{\text {tot }}$ (the subscript tot represents the total concentrations), the effects of varying $[\mathrm{BH}]_{\mathrm{tot}} /[\mathrm{PAH}]_{\text {tot }}$ on the oxidation rates were investigated in each of an extended series of reaction media. However, the variation of $[\mathrm{BH}]_{\mathrm{tot}} /[\mathrm{PAH}]_{\text {tot }}$ in each medium was controlled to not induce any $\mathrm{pH}$ changes in that particular medium. Plots of $k_{\mathrm{obsd}}$ versus [Hydrazide] $]_{\text {tot }}$ are illustrated in Figure 2 in the case of $\mathrm{BH}$ and in Figure 3 for the reaction of PAH. No doubt, these plots are linear and passing through the origin, indicating that the oxidation reactions are also first order in [Hydrazide $]_{\text {tot. }}$. Hence an empirical rate law (expressed by Equation (2)) is established, where $k^{\prime}$ represents the observed second-order rate constant and $k_{\mathrm{obsd}}=k^{\prime}[\text { Hydrazide }]_{\text {tot }}$.

$$
-\mathrm{d}\left[\operatorname{IrCl}_{6}{ }^{2-}\right] / \mathrm{dt}=k_{\mathrm{obsd}}\left[\mathrm{IrCl}_{6}{ }^{2-}\right]=k^{\prime}[\text { Hydrazide }]_{\mathrm{tot}}\left[\operatorname{IrCl}_{6}{ }^{2-}\right]
$$

The oxidation reaction of $\mathrm{BH}$ was investigated in a region of $0.11 \leq \mathrm{pH} \leq 10.46$; when $\mathrm{pH}>10.5$, the reaction became too fast to follow even by the stopped-flow technique. In the case of $\mathrm{PAH}$, the reaction was investigated in a wider $\mathrm{pH}$ region $(0.16 \leq \mathrm{pH} \leq 11.78)$ since the oxidation reaction of $\mathrm{PAH}$ was slower than that of $\mathrm{BH}$. Values of $k^{\prime}$ were computed from the linear plots of $k_{\text {obsd }}$ versus [Hydrazide] $]_{\text {tot }}$ at various pHs which were collected from a large amount of data, and are summarized in Table S1 in $\mathrm{SM}$. More visually, the plots of $\log k^{\prime}$ versus $\mathrm{pH}$ are given in Figure 4 (data points). 

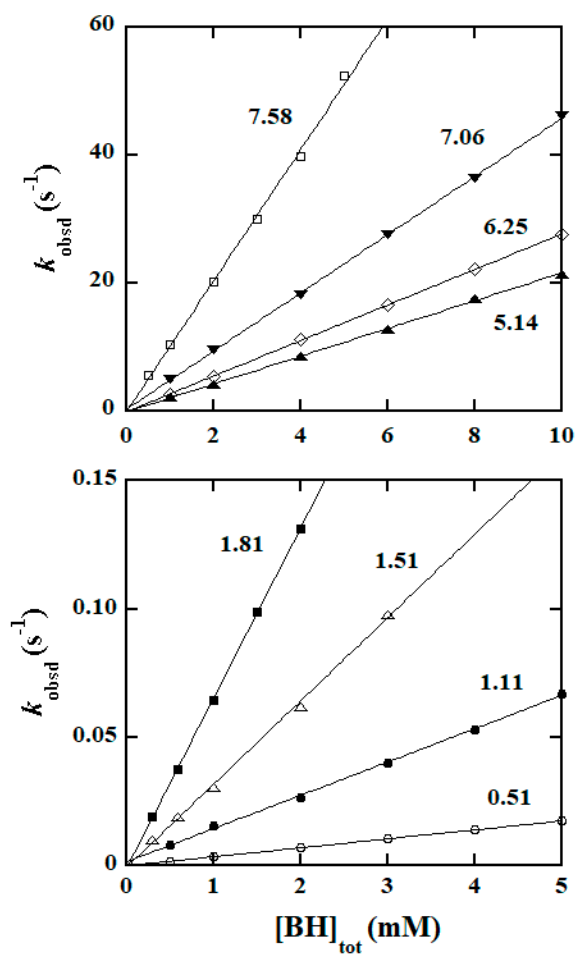

Figure 2. Plots of $k_{\text {obsd }}$ versus $[\mathrm{BH}]_{\text {tot }}$ at $25.0{ }^{\circ} \mathrm{C}$ and different $\mathrm{pHs}$ with the numbers around the lines indicating the $\mathrm{pH}$ values.
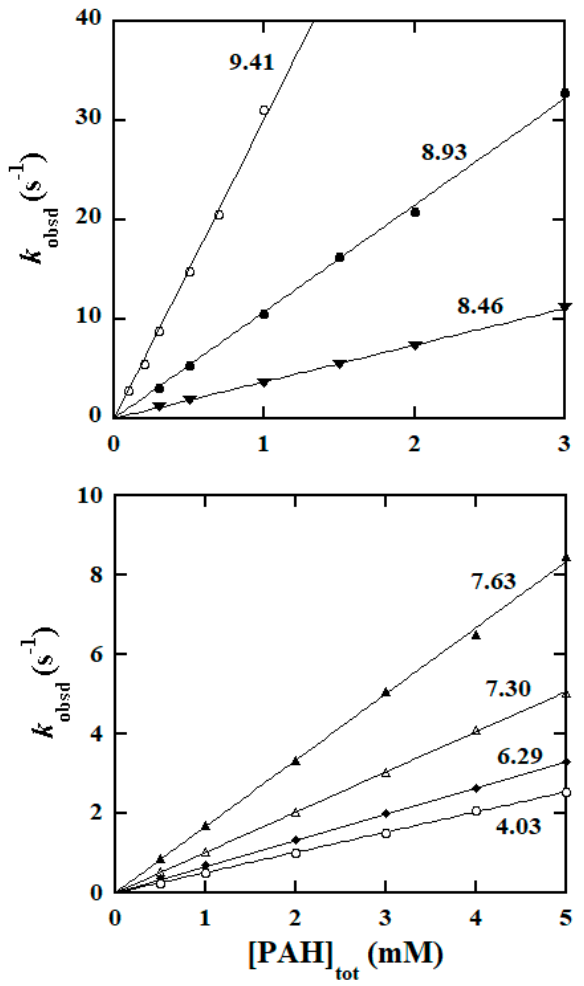

Figure 3. Plots of $k_{\text {obsd }}$ versus [PAH] tot (phenylacetic hydrazide) at $25.0^{\circ} \mathrm{C}$ and different pHs with the numbers around the lines indicating the $\mathrm{pH}$ values. 

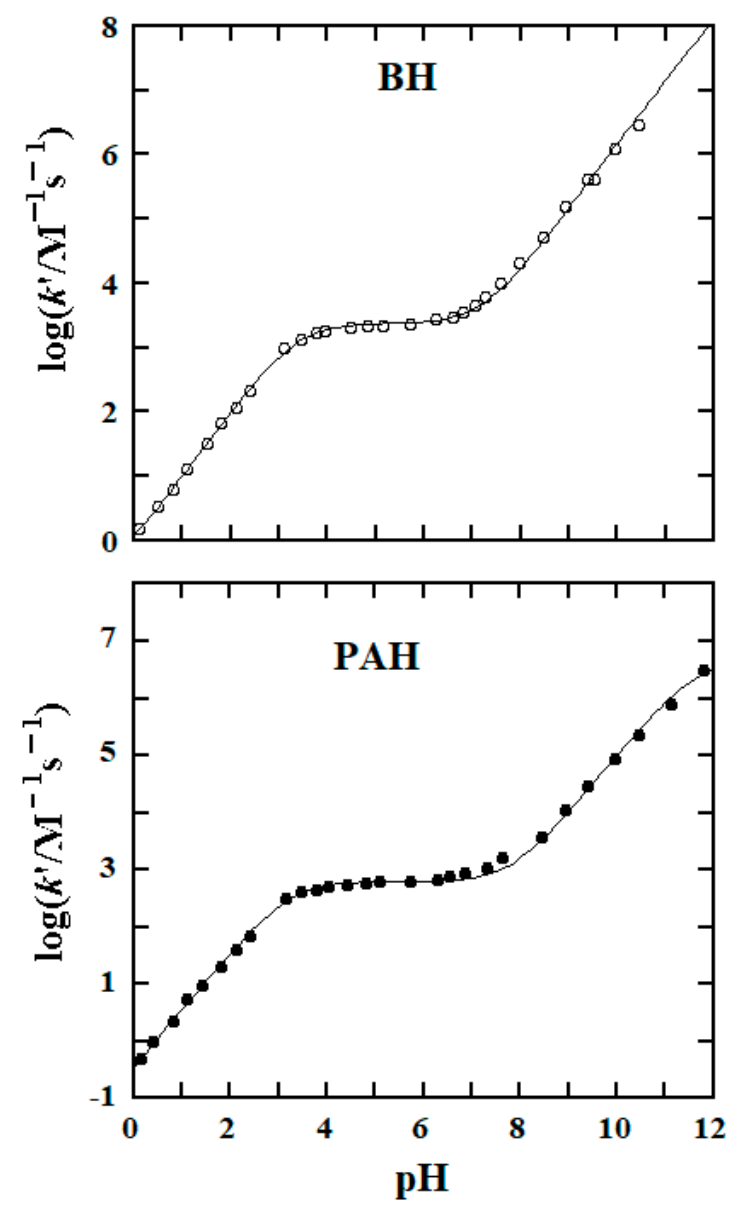

Figure 4. The $\log k^{\prime}$ versus $\mathrm{pH}$ profiles at $25.0^{\circ} \mathrm{C}$ plotted from the data points for the oxidations of $\mathrm{BH}$ and $\mathrm{PAH}$ by $\left[\mathrm{IrCl}_{6}\right]^{2-}$ (data points from Table S1 in Supplementary Materials). The solid curves were generated from the best fits of Equation (5) to the experimental data by a weighted nonlinear least-squares simulation.

\subsection{Evaluation of the Reaction Stoichiometry}

Spectrophotometric titration was proved to be a good method for determinations of reaction stoichiometries [14,28,29]; it was thus used in the present reaction systems (cf. the experimental section below). From the spectrophotometric titration data, plots of the measured absorbance at 488 $\mathrm{nm}$ as a function of $[\mathrm{BH}]_{\text {tot }}$ are given in Figures S3 and S4 in SM whereas similar plots for the PAH reaction are displayed in Figures S5 and S6 in SM. Clearly, in each of the four figures, all the data points could be traced by two crossing straight lines; from the intersection, a stoichiometric ratio $\Delta[\operatorname{Ir}(\mathrm{IV})]: \Delta[\text { Hydrazide }]_{\text {tot }}$ was estimated. The estimated ratios are summarized in Table 1. Obviously, the ratios in Table 1 point to a clean stoichiometry of $\Delta\left[\mathrm{IrCl}_{6}{ }^{2-}\right]: \Delta[\text { Hydrazide }]_{\text {tot }}=4: 1$. The same reaction stoichiometry was also derived previously for the oxidations of INH and hydrazines [14,28]. The stoichiometric reaction in the present cases can be described by Equation (3), where $n=0$ for $\mathrm{BH}$ and $n=1$ for PAH [14].

$$
\mathrm{C}_{6} \mathrm{H}_{5}-\left(\mathrm{CH}_{2}\right)_{n}-\mathrm{CONHNH}_{2}+4\left[\mathrm{IrCl}_{6}\right]^{2-}+\mathrm{H}_{2} \mathrm{O} \rightarrow \mathrm{C}_{6} \mathrm{H}_{5}-\left(\mathrm{CH}_{2}\right)_{\mathrm{n}}-\mathrm{COOH}+4\left[\mathrm{IrCl}_{6}\right]^{3-}+4 \mathrm{H}^{+}+\mathrm{N}_{2}
$$


Table 1. Stoichiometric ratios determined for oxidation reactions of $\mathrm{BH}$ and $\mathrm{PAH}$ by $\left[\mathrm{IrCl}_{6}\right]^{2-}$ at room temperature.

\begin{tabular}{ccc}
\hline Reductant & $\Delta[\mathbf{I r}(\mathbf{I V})]: \Delta[\text { Hydrazide }]_{\text {tot }}$ & Reaction Medium (Reaction Time) \\
\hline BH & $4.0: 1.03 \pm 0.03$ & $\mathrm{pH} \mathrm{6.31} \mathrm{phosphate} \mathrm{buffer}(5 \mathrm{~min})$ \\
& $4.0: 1.05 \pm 0.03$ & $0.010 \mathrm{M} \mathrm{HClO}_{4}(2 \mathrm{~h})$ \\
\hline PAH & $4.0: 0.097 \pm 0.03$ & $\mathrm{pH} \mathrm{6.31} \mathrm{phosphate} \mathrm{buffer}(30 \mathrm{~min})$ \\
& $4.0: 1.00 \pm 0.03$ & $0.010 \mathrm{M} \mathrm{HClO}_{4}(2 \mathrm{~h})$ \\
\hline
\end{tabular}

\subsection{Product Analysis}

To confirm the oxidation products as inferred by Equation (3), RP-HPLC was employed for the analysis of the reaction of $\mathrm{BH}$; Figure 5 displays the chromatogram acquired for a reaction mixture of $2.5 \mathrm{mM} \mathrm{BH}$ and $2.5 \mathrm{mM}\left[\mathrm{IrCl}_{6}\right]^{2-}$ in a phosphate buffer of $\mathrm{pH} 6.34$ after a reaction time of about $10 \mathrm{~min}$. In the figure, the peaks were assigned according to the retention times which were identical to those from authentic samples. Moreover, no late peaks in the chromatogram were eluted by an extended elution time. Hence, benzoic acid was identified as the oxidation product of $\mathrm{BH}$.

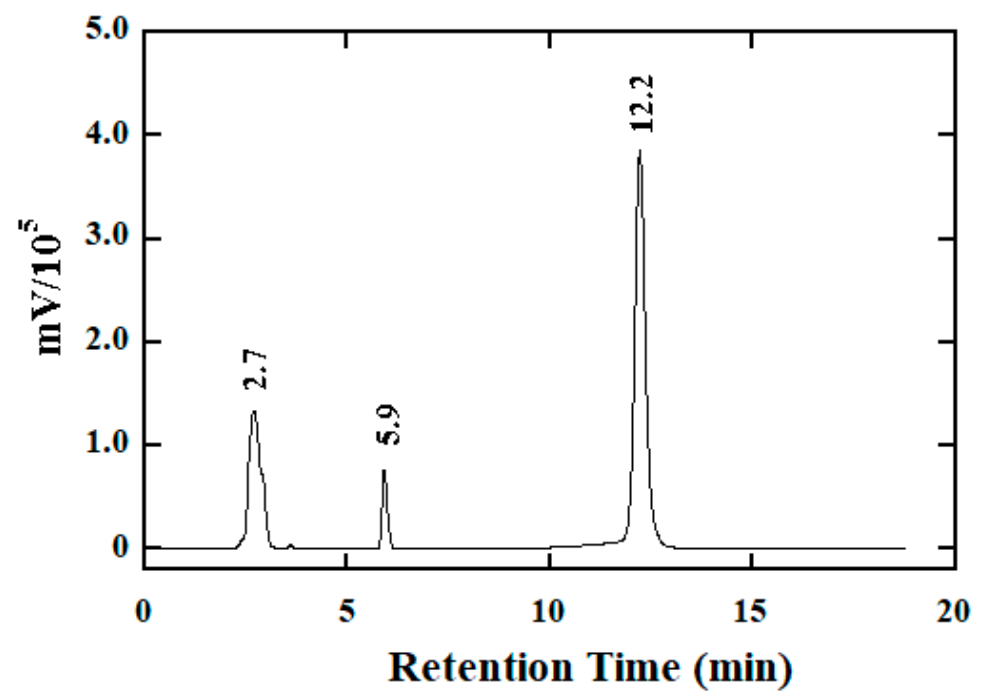

Figure 5. HPLC chromatogram obtained for a reaction mixture containing $2.5 \mathrm{mM}\left[\mathrm{IrCl}_{6}\right]^{2-}$ and $2.5 \mathrm{mM}$ $\mathrm{BH}$ in a phosphate buffer of $\mathrm{pH} 6.34$ after a reaction time of $10 \mathrm{~min}$. Peak assignments: Peak at $2.7 \mathrm{~min}$ for $\left[\mathrm{IrCl}_{6}\right]^{3-}$; Peak at $5.9 \mathrm{~min}$ for benzoic acid; Peak at $12.2 \mathrm{~min}$ for $\mathrm{BH}$. Chromatographic conditions: a solvent mixture of $\mathrm{H}_{2} \mathrm{O}: \mathrm{MeOH}=4: 1(v / v)$ was the mobile phase; the UV detector was set at $261 \mathrm{~nm}$; the flow rate was set at $1.0 \mathrm{~mL} / \mathrm{min}$.

For the oxidation of PAH by $\operatorname{Ir}(\mathrm{IV})$, the ${ }^{1} \mathrm{H}-\mathrm{NMR}$ spectra acquired are shown in Figure 6, together with the assignments of NMR signals; 3-(trimethylsilyl)propionic acid- $d_{4}$ sodium salt (TSP) was utilized as the reference of the NMR shifts in the spectra. The spectra indicate that when more than a stoichiometric amount of $\operatorname{Ir}(\mathrm{IV})$ was used in the reaction mixture, all the reactant PAH was cleanly oxidized to phenylacetic acid. It was observed that the excess of $\operatorname{Ir}(\mathrm{IV})$ could not oxidize phenylacetic acid that was produced from the oxidation reaction; this was not surprising since Ir(IV) did not oxidize the HAc-NaAc buffers. Phenylacetic acid was thus confirmed as the oxidation product of PAH, justifying Equation (3). 


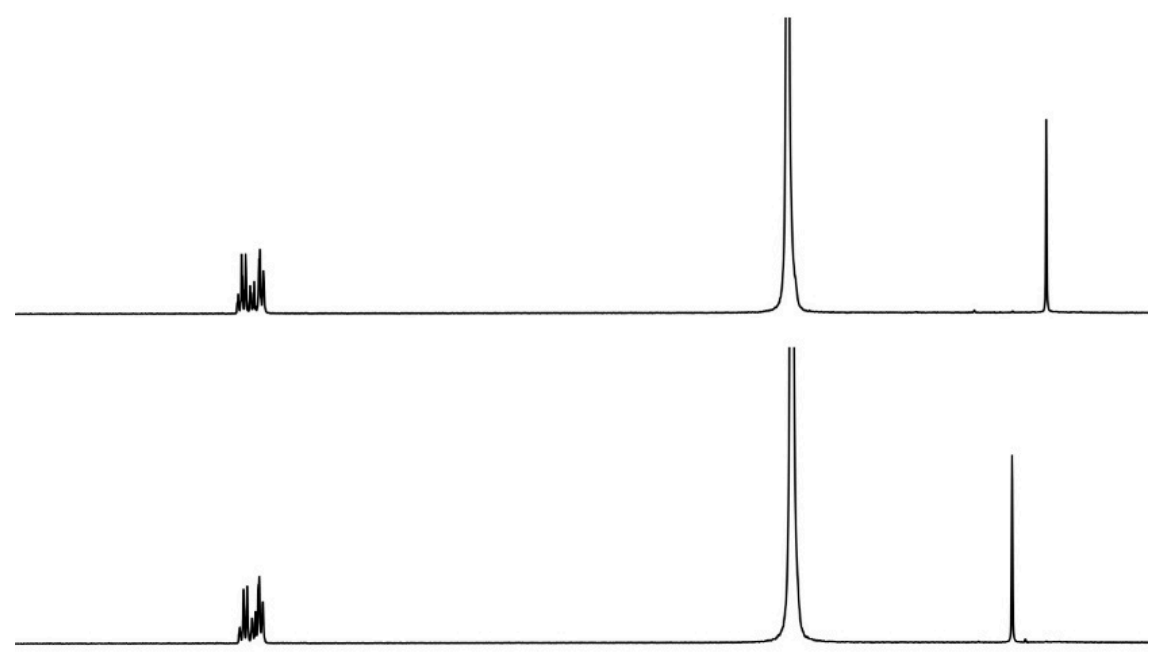

$\begin{array}{llllllllllllllllllllllllllllllllll}8.4 & 8.2 & 8.0 & 7.8 & 7.6 & 7.4 & 7.2 & 7.0 & 6.8 & 6.6 & 6.4 & 6.2 & 6.0 & 5.8 & 5.6 & 5.4 & 5.2 & 5.0 & 4.8 & 4.6 & 4.4 & 4.2 & 4.0 & 3.8 & 3.6 & 3.4 & 3.2\end{array}$

Figure 6. ${ }^{1} \mathrm{H}-\mathrm{NMR}$ spectra recorded on a 400-MHz NMR spectrometer. (Top): $1 \mathrm{mM}$ PAH in $\mathrm{D}_{2} \mathrm{O}$. Assignments of chemical shift for $\mathrm{C}_{6} \mathrm{H}_{5}-\mathrm{CH}_{2}-\mathrm{CONHNH}_{2}$ : $-\mathrm{CH}_{2^{-}}, \delta 3.59$ (s); $\mathrm{C}_{6} \mathbf{H}_{5^{-}}, \delta$ 7.32-7.44 (m). (Bottom): A reaction mixture of $1 \mathrm{mM} \mathrm{PAH}$ and $5 \mathrm{mM}\left[\mathrm{IrCl}_{6}\right]^{2-}$ in $\mathrm{D}_{2} \mathrm{O}$ after a reaction time of $5 \mathrm{~h}$. Assignments of chemical shift for $\mathrm{C}_{6} \mathrm{H}_{5}-\mathrm{CH}_{2}-\mathrm{COOH}$ : $-\mathrm{CH}_{2-}^{-}, \delta 3.75$ (s); $\mathrm{C}_{6} \mathrm{H}_{5^{-}}, \delta$ 7.32-7.43 (m).

\section{Discussion}

\subsection{Mechanistic Analysis}

For BH and PAH in aqueous solution in the present work, three protolysis species (I-III shown in Figure 7) are involved across the wide $\mathrm{pH}$ range used in present work [14]. The elucidated kinetic characters for the present reaction systems (such as well-defined second-order kinetics, rapid scan spectra, the reaction stoichiometry and the oxidation products) echo those revealed in the INH-Ir(IV) reaction system [14]. Moreover, even the shape of $\log k^{\prime}$ versus $\mathrm{pH}$ profiles in Figure 4 is also similar to that obtained for the INH-Ir(IV) reaction. By analog, a reaction mechanism portrayed in Figure 7 is suggested for the present reaction systems in which the reactions denoted by $k_{1}-k_{3}$ are the rate-determining steps. Two types of hydrazyl free radicals (species IV and V) were inferred to be generated in the rate-determining steps [11-14,26,27], and were followed by three consecutive and fast reactions, leading to formation of benzoic acid/phenylacetic acid [14].

Rate expression in Equation (4) was attained according to the reaction mechanism in Figure 7 , where $\mathrm{a}_{\mathrm{H}}$ represents the proton activity which corresponds exactly to the $\mathrm{pH}$ measurements.

$$
-\mathrm{d}\left[\operatorname{IrCl}_{6}{ }^{2-}\right] / \mathrm{dt}=\frac{4\left(k_{1} \mathrm{a}_{\mathrm{H}}{ }^{2}+k_{2} K_{\mathrm{a} 1} \mathrm{a}_{\mathrm{H}}+k_{3} K_{\mathrm{a} 1} K_{\mathrm{a} 2}\right)}{\mathrm{a}_{\mathrm{H}}{ }^{2}+K_{\mathrm{a} 1} \mathrm{a}_{\mathrm{H}}+K_{\mathrm{a} 1} K_{\mathrm{a} 2}}[\text { Hydrazide }]_{\text {tot }}\left[\operatorname{IrCl}_{6}{ }^{2-}\right]
$$

Equation (4) conforms to the empirical Equation (2), rendering:

$$
k^{\prime}=\frac{4\left(k_{1} \mathrm{a}_{\mathrm{H}}^{2}+k_{2} K_{\mathrm{a} 1} \mathrm{a}_{\mathrm{H}}+k_{3} K_{\mathrm{a} 1} K_{\mathrm{a} 2}\right)}{\mathrm{a}_{\mathrm{H}}^{2}+K_{\mathrm{a} 1} \mathrm{a}_{\mathrm{H}}+K_{\mathrm{a} 1} K_{\mathrm{a} 2}}
$$




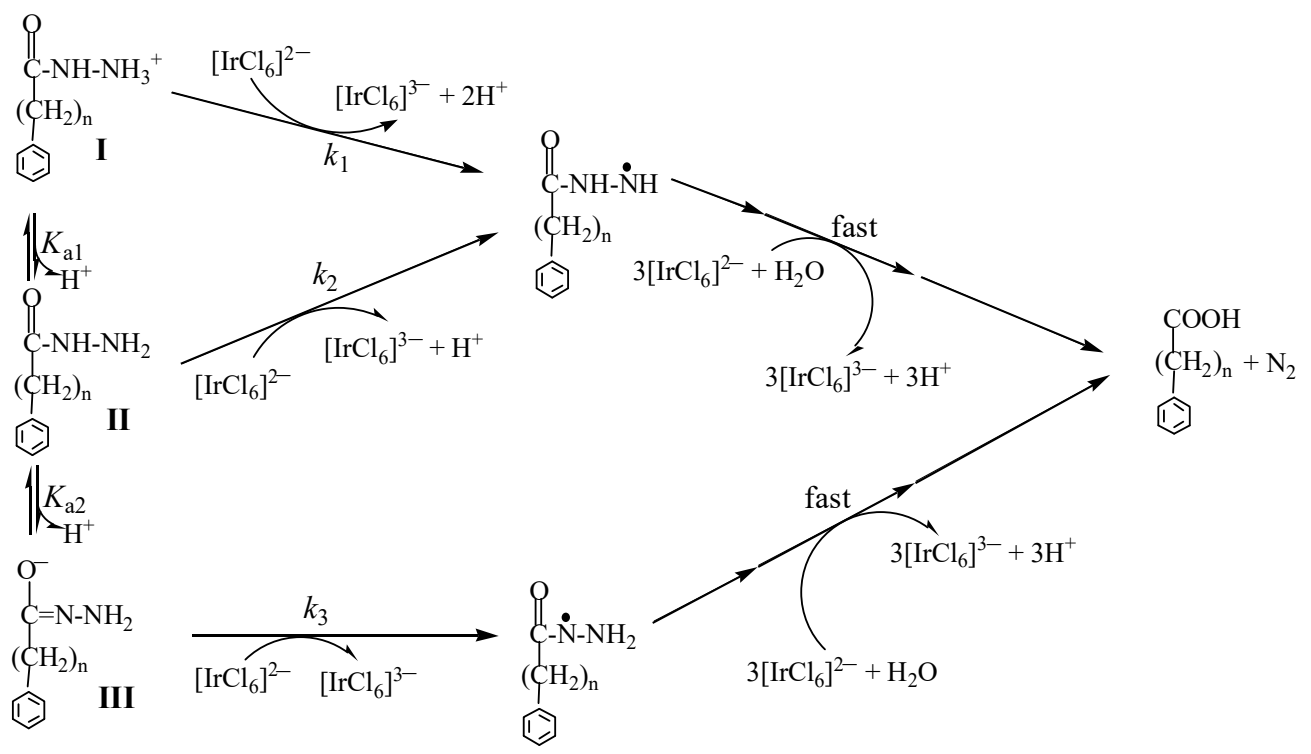

Figure 7. A reaction mechanism proposed for the oxidations of $\mathrm{BH}(n=0)$ and $\mathrm{PAH}(n=1)$ by $[\operatorname{IrCl6}]^{2-}$ in which the reactions described by $k_{1}-k_{3}$ are the rate-determining steps.

\section{2. $p K_{a}$ Values and Rate Constants of the Rate-Determining Steps}

Determination of $\mathrm{p} K_{\mathrm{a}}$ values for hydrazines from the well-defined kinetic data offered a good approach for the Ir(IV)-hydrazine reaction systems [28]; this was based on the measured kinetic data in the $\mathrm{pH}$ ranges covering the $\mathrm{p} K_{\mathrm{a}}$ values of hydrazines. For the present reaction systems, the protolysis constants $K_{\mathrm{a} 1}$ and $K_{\mathrm{a} 2}$ of $\mathrm{BH}$ and $\mathrm{PAH}$ at $25.0^{\circ} \mathrm{C}$ and $\mu=1.0 \mathrm{M}$ have not been reported in the literature. The $\mathrm{pH}$ range studied for the PAH reaction was from $0.16 \mathrm{pH} 11.78$, probably covering both $\mathrm{p} K_{\mathrm{a} 1}$ and $\mathrm{p} K_{\mathrm{a} 2}$ of $\mathrm{PAH}$, and consequently enabling us to derive these $\mathrm{p} K_{\mathrm{a}}$ values from our kinetic data. Equation (5) was then utilized to simulate the $k^{\prime}$-pH dependence data by use of a weighted nonlinear least-squares method; in the simulation, $k_{1}, k_{2}, k_{3}, K_{\mathrm{a} 1}$ and $K_{\mathrm{a} 2}$ were all treated as tunable parameters. The simulation provided with a good fit shown in the bottom part of Figure 4, conferring simultaneously the values for these parameters (listed in Table 2). The value of $\mathrm{p} K_{\mathrm{a} 2}=11.7 \pm 0.2$ obtained from the simulation is indeed within the $\mathrm{pH}$ region studied kinetically.

Table 2. Rate constants for the rate-determining steps and protolysis constants in Figure 7 for the reactions of $\mathrm{BH}$ and $\mathrm{PAH}$ determined at $25.0^{\circ} \mathrm{C}$ and ionic strength $\mu=1.0 \mathrm{M}$.

\begin{tabular}{ccc}
\hline Hydrazide & $k_{\mathrm{m}} / \mathrm{p} K_{\mathrm{am}}$ & Values \\
\hline $\mathrm{BH}$ & $k_{1}$ & $0.046 \pm 0.013 \mathrm{M}^{-1} \mathrm{~s}^{-1}$ \\
& $k_{2}$ & $597 \pm 9 \mathrm{M}^{-1} \mathrm{~s}^{-1}$ \\
& $k_{3}$ & $(1.47 \pm 0.05) \times 10^{8} \mathrm{M}^{-1} \mathrm{~s}^{-1}$ \\
& $\mathrm{p} K_{\mathrm{a} 1}$ & $12.37 \pm 0.09$ \\
$\mathrm{p} K_{\mathrm{a} 2}$ & 0 (or indeterminate) \\
& $k_{1}$ & $157 \pm 5 \mathrm{M}^{-1} \mathrm{~s}^{-1}$ \\
& $k_{2}$ & $(1.19 \pm 0.06) \times 10^{6} \mathrm{M}^{-1} \mathrm{~s}^{-1}$ \\
& $k_{3}$ & $3.24 \pm 0.08$ \\
& $\mathrm{p} K_{\mathrm{a} 1}$ & $11.7 \pm 0.2$ \\
\hline
\end{tabular}

The $\mathrm{p} K_{\mathrm{a} 1}$ value of $\mathrm{BH}$ is expected to be between 3 and 4 [30], which is in the $\mathrm{pH}$ region studied kinetically in this work while that of $\mathrm{p} K_{\mathrm{a} 2}$ is anticipated to be $>12$ at $25.0{ }^{\circ} \mathrm{C}$ and $\mu=1.0 \mathrm{M}$ [30], being beyond the $\mathrm{pH}$ region of the kinetic data collection. We thus determined the $\mathrm{p} K_{\mathrm{a} 2}$ value of $\mathrm{BH}$ spectrophotometrically [31]. The UV-vis spectra recorded for $0.10 \mathrm{mM} \mathrm{BH}$ in the buffer solutions of pH 6.00 and 12.68 are given in the top part of Figure 8, where the spectra originate predominantly 
from species II and III of BH, respectively. The wavelength of $275 \mathrm{~nm}$ was then employed for the measurements of absorption values.

A series of $\mathrm{BH}$ solutions with varied $\mathrm{pH}$ buffers were prepared in which $[\mathrm{BH}]_{\text {tot }}=0.10 \mathrm{mM}$ was kept constant; absorption values at $275 \mathrm{~nm}$ were measured after those solutions were equilibrated at $25.0^{\circ} \mathrm{C}$ for $10 \mathrm{~min}$. The measured value as a function of $\mathrm{pH}$ is given in the bottom part of Figure 8 (data points).

$$
\left.\left.\operatorname{Abs}(275 \mathrm{~nm})=[\mathrm{BH}]_{\text {tot }}\left\{\varepsilon_{3}+\varepsilon_{2} \cdot 10^{(\mathrm{pK}}{ }_{\mathrm{a} 2}-\mathrm{pH}\right)\right\} /\left\{1+10^{(\mathrm{pK}}{ }_{\mathrm{a} 2}-\mathrm{pH}\right)\right\}
$$

Equation (6) was then employed to simulate the data [31], using a nonlinear squares method, where $\varepsilon_{2}$ and $\varepsilon_{3}$ represent the molar absorptivities of species II and III, respectively. The simulation resulted in a good fit, generating the values of $\varepsilon_{2}=(1.00 \pm 0.02) \times 10^{3} \mathrm{M}^{-1} \mathrm{~cm}^{-1}, \varepsilon_{3}=(7.3 \pm 0.4) \times 10^{3}$ $\mathrm{M}^{-1} \mathrm{~cm}^{-1}$, and $\mathrm{p} K_{\mathrm{a} 2}=12.6 \pm 0.1$ at $25.0^{\circ} \mathrm{C}$ and $\mu=1.0 \mathrm{M}$.

Equation (5) was then used to simulate the $k^{\prime}-\mathrm{pH}$ dependence data for the $\mathrm{BH}$ reaction; in the simulation, $k_{1}, k_{2}, k_{3}$, and $K_{\mathrm{a} 1}$ were treated as adjustable parameters and the value of $K_{\mathrm{a} 2}$ obtained above was used as a direct input. The simulation provided an excellent fit shown in the top part of Figure 4 whereas the acquired values of $k_{1}, k_{2}, k_{3}$, and $K_{\mathrm{a} 1}$ are listed in Table 2.
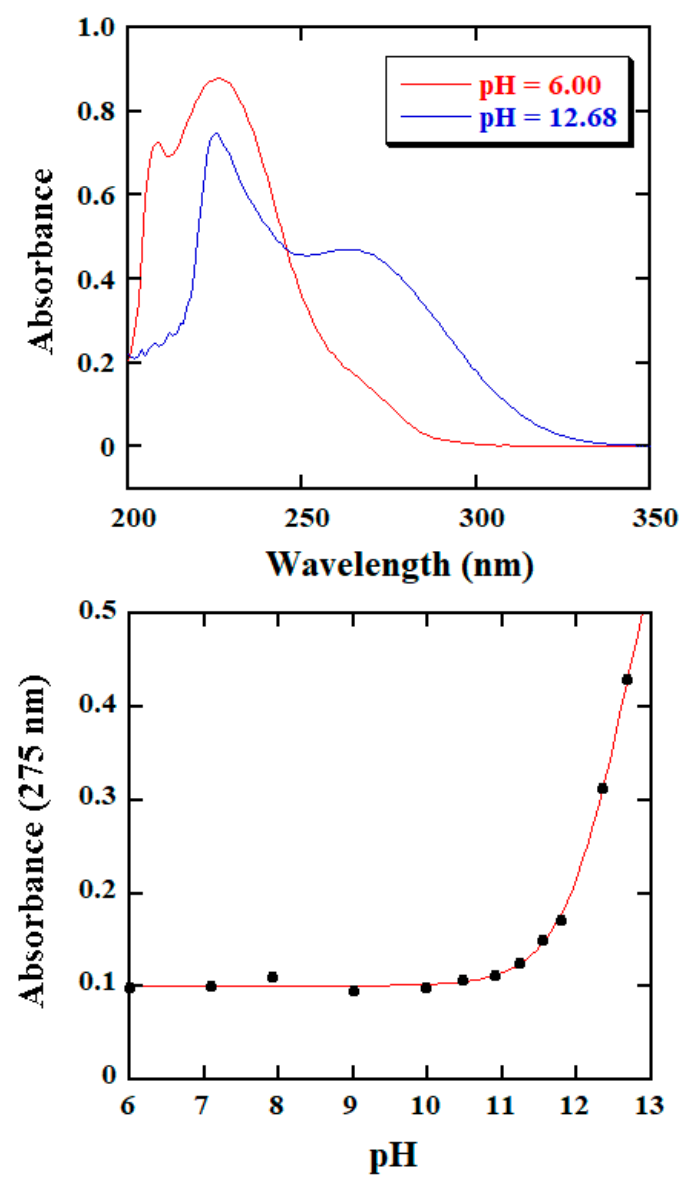

Figure 8. (Top): UV-vis spectra of $0.10 \mathrm{mM} \mathrm{BH}$ in two buffers of different $\mathrm{pH}$ at $25.0^{\circ} \mathrm{C}$ and $\mu=1.0 \mathrm{M}$. (Bottom): Absorbance at $275 \mathrm{~nm}$ of $0.10 \mathrm{mM} \mathrm{BH}$ solutions as function of $\mathrm{pH}$ at $25.0^{\circ} \mathrm{C}$ and $\mu=1.0 \mathrm{M}$. The solid curve was obtained from the best fit of Equation (6) to the experimental data using a nonlinear least-squares method.

\subsection{Probing the Activation Process}

After evaluation of the protolysis constants and the rate constants of the rate-determining steps, we were able to create species of $\mathrm{BH} / \mathrm{PAH}$ versus $\mathrm{pH}$ distribution diagrams (the top parts of Figures $\mathrm{S} 7$ and $\mathrm{S} 8$ in $\mathrm{SM}$ ) and the reactivity of $\mathrm{BH} / \mathrm{PAH}$ species versus $\mathrm{pH}$ distribution diagrams (bottom parts of 
Figures S7 and S8 in SM) [14]. Figures S7 and S8 demonstrate that species II of BH/PAH (cf. Figure 7) contributes predominantly in both distributions between $\mathrm{pH} 5$ and 6 , which corresponds to the plateau regions in the $\log k^{\prime}$ versus $\mathrm{pH}$ plots. In this small region, Equation (5) can be simplified to $k^{\prime} \approx 4 k_{2}$ (or $k_{2} \approx k^{\prime} / 4$ ). The oxidation reactions were thus investigated at several temperatures in this region; the results are summarized in Figures S9 and S10 in SM (the top parts) and in Table 3. The Eyring plots for $k_{2}$ are displayed in the bottom parts of Figures S9 and S10 for the reactions of BH and PAH. Activation parameters were calculated from these plots and are also listed in Table 3. Activation entropies $\Delta S_{2}^{\ddagger}=-72 \mathrm{~J} \cdot \mathrm{K}^{-1} \cdot \mathrm{mol}^{-1}$ for BH and $\Delta S_{2}^{\ddagger}=-66 \mathrm{~J} \cdot \mathrm{K}^{-1} \cdot \mathrm{mol}^{-1}$ for PAH are very close to each other and are of the middle-ranged negative values. These values, reflecting the activation processes between $\left[\mathrm{IrCl}_{6}\right]^{2-}$ and the neutral forms of $\mathrm{BH}$ and PAH, are consistent favorably with the nature of the second-order kinetics, where a compact structure of the transition state is expected. When the salient features of the rapid scan spectra are put together with the middle-ranged negative values of activation entropies, an outer-sphere electron transfer likely took place in the rate-determining step denoted by $k_{2}[14,28]$. The same mode of electron transfer is expected to occur for the reactions expressed by $k_{1}$ and $k_{3}$ although it was not possible to determine the activation parameters for these reactions.

Table 3. Rate constant $k_{2}$ as a function of temperature and activation parameters for oxidation of the neutral forms of $\mathrm{BH}$ and $\mathrm{PAH}$ defined in Figure 7 by $\left[\mathrm{IrCl}_{6}\right]^{2-}$ at $\mu=1.0 \mathrm{M}$.

\begin{tabular}{|c|c|c|c|c|}
\hline Hydrazide & $t /{ }^{\circ} \mathrm{C}$ & $k_{2} / \mathbf{M}^{-1} \mathbf{s}^{-1}$ & $\Delta H_{2}^{\ddagger} / \mathrm{kJ} \cdot \mathrm{mol}^{-1}$ & $\Delta S_{2} \ddagger / J \cdot K^{-1} \cdot \mathrm{mol}^{-1}$ \\
\hline \multirow[t]{5}{*}{$\mathrm{BH}$} & 15.0 & $297 \pm 9$ & $36.2 \pm 0.7$ & $-72 \pm 5$ \\
\hline & 20.0 & $397 \pm 15$ & & \\
\hline & 25.0 & $521 \pm 20$ & & \\
\hline & 30.0 & $654 \pm 25$ & & \\
\hline & 35.0 & $857 \pm 27$ & & \\
\hline \multirow[t]{5}{*}{$\mathrm{PAH}$} & 15.0 & $86 \pm 2$ & $40.7 \pm 0.9$ & $-66 \pm 4$ \\
\hline & 20.0 & $119 \pm 3$ & & \\
\hline & 25.0 & $158 \pm 4$ & & \\
\hline & 30.0 & $205 \pm 5$ & & \\
\hline & 35.0 & $283 \pm 9$ & & \\
\hline
\end{tabular}

\subsection{Comparison of the Rate Constants}

For the oxidations of aryl hydrazides by $\left[\mathrm{IrCl}_{6}\right]^{2-}$, the most surprising observation was that the reactivities of the protolysis species of hydrazides vary by about nine orders of magnitude [14]. This huge reactivity difference is also observed in the oxidation reaction of $\mathrm{BH}$ by $\left[\mathrm{IrCl}_{6}\right]^{2-}$, being as $k_{1}: k_{2}: k_{3}=1: 1.3 \times 10^{4}: 3.2 \times 10^{9} . \mathrm{BH}$ is very close to INH in structure and the reactivities of its neutral and enolate forms are about the same as those of INH. INH is a frontline anti-tubercular drug but $\mathrm{BH}$ has essentially no anti-tubercular activity. Thus, the vital role played by the pyridine nitrogen in INH is not related directly to their reactivity in the reduction of a single electron oxidant. For the PAH- $\left[\mathrm{IrCl}_{6}\right]^{2-}$ reaction, the ratio of $k_{2}: k_{3}=1: 7.6 \times 10^{3}$ becomes smaller but is still large. Thus, it can be concluded that the enolate forms of aryl hydrazides are exceptionally reactive towards reduction of $\left[\mathrm{IrCl}_{6}\right]^{2-}$. This exceptionally high reactivity makes it possible that aryl hydrazides are potentially good candidates for antioxidants [32]. This also accounts for the good chemical preserving properties of hydrazides [2]. Another surprising observation in this work is that a methylene group reduces the reactivity of the enolate form of $\mathrm{PAH}$ about 120 times from that of $\mathrm{BH}$.

\subsection{Structure-Reactivity Relationship}

Table 4 summarizes the main results acquired so far for the oxidations of hydrazides by $\left[\mathrm{IrCl}_{6}\right]^{2-}$ including a very recent one (2-furoic hydrazide (FH), cf. Figure S1 in SM) studied by the Shi group [33]. The $\mathrm{pK}_{\mathrm{a}}$ values for the deprotonation of $\mathrm{R}-\mathrm{CONHNH}{ }_{3}{ }^{+}$locate in a small region, only varying from 3.04 to 3.67 whereas the reactivity of the neutral forms of hydrazides changes from 157 to 1120 
$\mathrm{M}^{-1} \mathrm{~s}^{-1}$. Clearly, there is no correlation between the reactivity and $\mathrm{p} K_{\mathrm{a}}$ values (Table 4 ), which supports the conclusion drawn in the oxidations of hydrazine and substituted hydrazines by $\left[\mathrm{IrCl}_{6}\right]^{2-}[28]$. On the other hand, a linear correlation is found between the reactivity of the enolate forms of the aryl

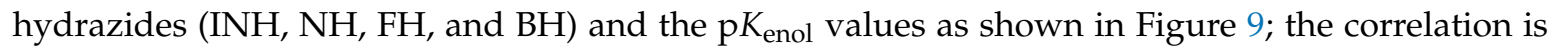
expressed by: $\log k_{\text {enolate }}=(0.16 \pm 0.07) \mathrm{p} K_{\text {enol }}+(6.1 \pm 0.8)$. The big intercept and the small slope of the correlation indicate that the intrinsic reactivities of the enolate forms of aryl hydrazides are very high but are not very sensitive to the enolate basicities. These characters may pave a way for a rational design of new antioxidants based on aryl hydrazides. PAH no longer being an aryl hydrazide drops the correlation, suggesting that other aliphatic hydrazides may fall off the correlation as well. Hence, more data are needed to test whether aliphatic hydrazides together with PAH will follow another correlation.

Table 4. A summary of the major results for the oxidations of hydrazides by $\left[\operatorname{IrC}_{16}\right]^{2-}$ at $25.0{ }^{\circ} \mathrm{C}$ and $\mu=1.0 \mathrm{M}$.

\begin{tabular}{cccccc}
\hline Hydrazide & $\mathbf{p} \boldsymbol{K}_{\mathbf{a}}{ }^{\mathbf{a}}$ & $\boldsymbol{k} / \mathbf{M}^{-\mathbf{1}} \mathbf{s}^{\mathbf{- 1} \mathbf{b}}$ & $\mathbf{p} \boldsymbol{K}_{\text {enol }} \mathbf{c}$ & $\boldsymbol{k}_{\text {enolate }} / \mathbf{M}^{-\mathbf{1}} \mathbf{s}^{\mathbf{- 1} \mathbf{d}}$ & Ref. \\
\hline INH & 3.67 & $1.13 \times 10^{3}$ & 10.89 & $7.9 \times 10^{7}$ & {$[14]$} \\
NH & 3.49 & 261 & 11.35 & $9.1 \times 10^{7}$ & {$[14]$} \\
FH & 3.04 & 620 & 11.6 & $7.3 \times 10^{7}$ & {$[34]$} \\
BH & 3.37 & 597 & 12.6 & $1.47 \times 10^{8}$ & This Work \\
PAH & 3.24 & 157 & 11.7 & $1.19 \times 10^{6}$ & This Work \\
\hline
\end{tabular}

${ }^{\mathrm{a}} \mathrm{p} \mathrm{K}_{\mathrm{a}}$ for $\mathrm{RCO}-\mathrm{NH}-\mathrm{NH}_{3}{ }^{+}$; ${ }^{\mathrm{b}}$ Second-order rate constant for $\mathrm{RCO}-\mathrm{NH}-\mathrm{NH}_{2} ;{ }^{\mathrm{c}} \mathrm{p} K_{\mathrm{a}}$ for the enol form of hydrazide; $\mathrm{d}$ The second-order rate constant for oxidation of enolate form of hydrazides by $\left[\mathrm{IrCl}_{6}\right]^{2-}$.

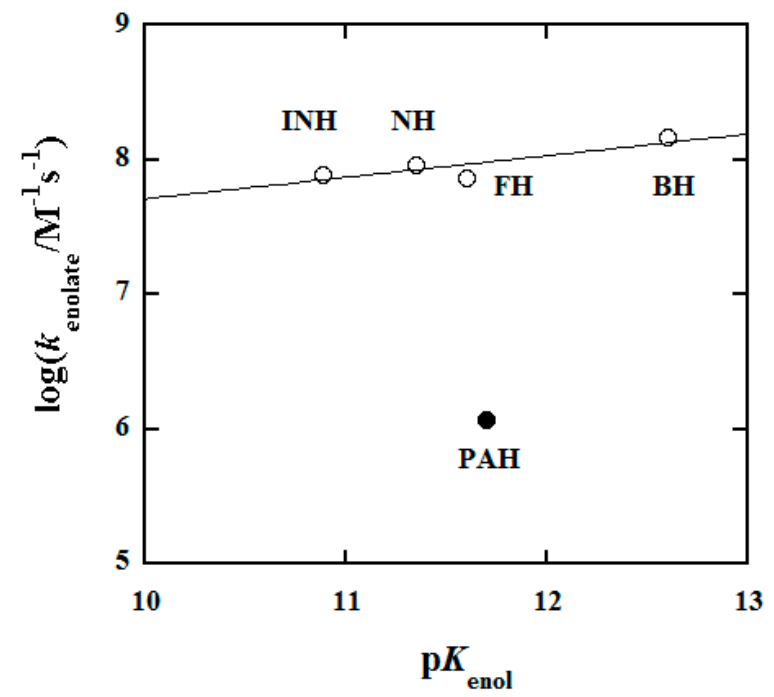

Figure 9. Plot of $\log k_{\text {enolate }}$ versus $\mathrm{p} K_{\mathrm{enol}}$ in the oxidation reactions of hydrazides by $\left[\mathrm{IrCl}_{6}\right]^{2-}$ in aqueous solution at $25.0^{\circ} \mathrm{C}$ and $\mu=1.0 \mathrm{M}$. INH, NH, $\mathrm{FH}$, and $\mathrm{BH}$ are aryl hydrazides.

\section{Materials and Methods}

\subsection{Chemicals}

Benz(o)hydrazide (BH, 98\%), phenylacetic hydrazide (PAH, 98\%), benzoic acid, sodium hexachloroiridate(IV) hexahydrate $\left(\mathrm{Na}_{2} \mathrm{IrCl}_{6} \cdot 6 \mathrm{H}_{2} \mathrm{O}, 99.9 \%\right)$, and 2,4-pyridinedicarboxylic acid (PDCA, $\geq 98 \%$ ) were purchased from Sigma-Aldrich (Sigma Shanghai Branch, China). The purity of BH and PAH was checked by RP-HPLC and ${ }^{1} \mathrm{H}-\mathrm{NMR}$ spectroscopy, respectively, confirming a good purity. Acetic acid, sodium acetate, sodium dihydrogen phosphate, disodium hydrogen phosphate, trisodium phosphate, sodium bicarbonate, sodium carbonate, sodium chloride, hydrochloric acid, perchloric acid, sodium perchlorate, $\mathrm{D}_{2} \mathrm{O}$ and TSP were obtained either from Alfa Aesar or from Fisher Scientific (Alfa 
Aesar Shanghai Branch and Fisher Shanghai Branch, China); these chemicals were all of analytical grade and used without further purification. Methanol in HPLC grade and standard buffers of $\mathrm{pH}$ $4.00,7.00$, and 10.00 were also obtained from Fisher Scientific. Doubly distilled water was utilized to prepare all the solutions.

\subsection{Buffers and Reaction Media}

The following buffering pairs of $\mathrm{AcOH} / \mathrm{NaOAc}, \mathrm{NaH}_{2} \mathrm{PO}_{4} / \mathrm{Na}_{2} \mathrm{HPO}_{4}, \mathrm{NaHCO}_{3} / \mathrm{Na}_{2} \mathrm{CO}_{3}$, and $\mathrm{Na}_{2} \mathrm{HPO}_{4} / \mathrm{Na}_{3} \mathrm{PO}_{4}$ (all about $0.2 \mathrm{M}$ ) were combined to cover the $\mathrm{pH}$ range from 3.15 to 12.68 ; all the buffers which contained $2 \mathrm{mM}$ PDCA [19] were adjusted to an ionic strength $(\mu)$ of $1.0 \mathrm{M}$ by use of $\mathrm{NaClO}_{4}$. The $\mathrm{pH}$ values were measured immediately before use with an Accumet Basic AB150 Plus pH meter equipped with an Accumet combination $\mathrm{pH}$ electrode (Fisher Scientific, Pittsburgh, PA, USA); the electrode was calibrated by use of the standard buffers of $\mathrm{pH} 4.00,7.00$, and 10.00 before the $\mathrm{pH}$ measurements. The acidic reaction media were prepared by use of the combinations of $1.00 \mathrm{M} \mathrm{HClO}_{4}$ and $1.00 \mathrm{M} \mathrm{NaClO}_{4}$ solutions, where $\left[\mathrm{H}^{+}\right]=\left[\mathrm{HClO}_{4}\right]$. For these media, their $\mathrm{pH}$ values were estimated by: $\mathrm{pH}=-\log \left[\mathrm{H}^{+}\right]+0.11$, which is based on a mean activity coefficient of 0.77 in solutions of $1.00 \mathrm{M}$ $\mathrm{NaClO}_{4}[34]$.

\subsection{Stoichiometric Investigation}

The reactions were investigated in two reaction media: a phosphate buffer of $\mathrm{pH} 6.31$ and an acidic medium of $\left[\mathrm{H}^{+}\right]=0.010 \mathrm{M}$. A series of solution mixtures were prepared in which $\left[\mathrm{IrCl}_{6}{ }^{2-}\right]=0.40 \mathrm{mM}$ was remained constant and [Hydrazine] tot was varied from 0 to $0.40 \mathrm{mM}$ in each of the two media, where $[\text { Hydrazide }]_{\text {tot }}=[\mathrm{BH}]_{\text {tot }} /[\mathrm{PAH}]_{\text {tot }}$ and the subscript pertains to total concentration. The reaction mixtures were aged for certain times, then the absorbance was measured at $488 \mathrm{~nm}$ employing a TU-1950 spectrophotometer (Persee Inc., Beijing, China) and $1.00 \mathrm{~cm}$ quartz cells. The spectrophotometer was connected to a water bath circulation from a thermostat (Lauda Alpha RA8, Belran, NJ, USA). The temperature could be controlled to $\pm 0.1^{\circ} \mathrm{C}$ (vide infra).

\subsection{Product Analysis by RP-HPLC and NMR Spectra}

For identification of the oxidation product of $\mathrm{BH}$, reaction mixtures of $\mathrm{BH}$ with $\left[\mathrm{IrCl}_{6}\right]^{2-}$ were analyzed by reversed-phase high performance liquid chromatography (RP-HPLC) using a Shimadzu LC-20 AD HPLC system equipped with a UV detector (Shimadzu Corporation, Kyoto, Japan). A C18 column of Shimadzu ( $250 \times 4.6 \mathrm{~mm}, 5 \mu \mathrm{m}$ in particle size) and an injection loop of $20 \mu \mathrm{L}$ were used for sample separations and injections. Moreover, the injection loop was always fully filled with samples. After optimizations of mobile phase in an isocratic elution mode, a solvent mixture of $\mathrm{H}_{2} \mathrm{O}: \mathrm{MeOH}=4: 1$ $(v / v)$ was chosen as the mobile phase. The UV detector was set at $261 \mathrm{~nm}$ and the flow rate was at $1.0 \mathrm{~mL} / \mathrm{min}$. Under the optimized conditions, a reaction mixture containing $2.5 \mathrm{mM} \mathrm{BH}$ and $2.5 \mathrm{mM}$ $\left[\mathrm{IrCl}_{6}\right]^{2-}$ in a phosphate buffer of $\mathrm{pH} 6.34$ after a reaction time of $10 \mathrm{~min}$ was subjected to analysis.

In the case of PAH, ${ }^{1} \mathrm{H}-\mathrm{NMR}$ spectroscopy (AVANCE NEO $400 \mathrm{MHz}$ NMR spectrometer, Bruker, Switzerland) was utilized to analyze the oxidation product. Two samples were prepared for NMR experiments: (a) $1 \mathrm{mM}$ PAH in $\mathrm{D}_{2} \mathrm{O}$ which contained $0.02 \%$ TSP and (b) a reaction mixture of $1 \mathrm{mM}$ $\mathrm{PAH}$ and $5 \mathrm{mM}\left[\mathrm{IrCl}_{6}\right]^{2-}$ after a reaction time of about $5 \mathrm{hrs}$.

\subsection{Kinetic Measurements}

A stock solution of $1.0 \mathrm{mM}\left[\mathrm{IrCl}_{6}\right]^{2-}$ was prepared and used daily by dissolving the desired amount of $\mathrm{Na}_{2} \mathrm{IrCl}_{6} \cdot 6 \mathrm{H}_{2} \mathrm{O}$ in a solution mixture containing $0.99 \mathrm{M} \mathrm{NaClO}_{4}$ and $0.01 \mathrm{M} \mathrm{HCl}$. Stock solutions of $\mathrm{BH} / \mathrm{PAH}$ were prepared by adding the required amount of $\mathrm{BH} / \mathrm{PAH}$ into a reaction medium of specific $\mathrm{pH}$ and then flushed for $5 \mathrm{~min}$ with nitrogen of high purity. For kinetic measurements, solutions of $\left[\mathrm{IrCl}_{6}\right]^{2-}$ and $\mathrm{BH} / \mathrm{PAH}$ were prepared by dilution of the stock solutions with the same medium and then flushed for about $5 \mathrm{~min}$ with the nitrogen. Reactions were initiated by mixing equal volumes of the $\left[\mathrm{IrCl}_{6}\right]^{2-}$ and $\mathrm{BH} / \mathrm{PAH}$ solutions directly on an SX-20 stopped-flow spectrometer (Applied 
Photophysics Ltd., Leatherhead, UK); the temperature was also controlled to $\pm 0.1^{\circ} \mathrm{C}$ using another thermostat of Lauda Alpha RA8. Moreover, the reaction solutions were only used for a couple of hours. The reactions were investigated under pseudo first-order conditions with $[\mathrm{Hydrazide}]_{\text {tot }} \geq 10 \cdot\left[\operatorname{IrCl}_{6}{ }^{2-}\right]$.

\section{Conclusions}

The oxidation reactions of $\mathrm{BH}$ and $\mathrm{PAH}$ by $\left[\mathrm{IrCl}_{6}\right]^{2-}$ have been characterized in a wide $\mathrm{pH}$ range by use of stopped-flow spectral, rapid spectral scan, RP-HPLC, and NMR spectroscopic techniques. The nature of well-defined second-order kinetics of the reactions warrants the evaluation of the rate constants of rate-determining steps and the protolysis constants for both $\mathrm{BH}$ and PAH. This work clearly confirmed the earlier findings made by the Shi group [14] that the enolate forms of aryl hydrazides have exceptionally high reactivities towards reduction of $\operatorname{Ir}(\mathrm{IV})$. Moreover, for the aryl hydrazides, a linear correction of $\log k_{\text {enolate }}=(0.16 \pm 0.07) \mathrm{p} K_{\text {enol }}+(6.1 \pm 0.8)$ is unraveled for the first time. Collectively, this work together with previous investigations [14,33] may pave a way for a rational design of new antioxidants based on aryl hydrazides. Additionally, the present work also offers the $\mathrm{p} K_{\mathrm{a}}$ values for $\mathrm{BH}$ and $\mathrm{PAH}$ at $25.0^{\circ} \mathrm{C}$ and $\mu=1.0 \mathrm{M}$.

Supplementary Materials: The following are available online, Table S1: Observed second-order rate constants $k^{\prime}$ for oxidations of $\mathrm{BH}$ and $\mathrm{PAH}$ by $\left[\mathrm{IrCl}_{6}\right]^{2-}$ as a function of $\mathrm{pH}$ at $25.0{ }^{\circ} \mathrm{C}$ and $1.0 \mathrm{M}$ ionic strength. Figure S1: Structures of hydrazides including aryl hydrazides $\mathrm{BH}, \mathrm{INH}, \mathrm{NH}$, and FH. Figure S2: Kinetic traces acquired from the data points in Figure 1. The solid curves were obtained from the best fits of the experimental data to Equation (1). Figure S3: Spectrophotometric titration: absorbance at $488 \mathrm{~nm}$ for a series of reaction mixtures of $\left[\mathrm{IrCl}_{6}\right]^{2-}$ with $\mathrm{BH}$ in which $[\mathrm{BH}]_{\text {tot }}$ was changed from 0 to $0.40 \mathrm{mM}$ and $[\operatorname{Ir}(\mathrm{IV})]=0.40 \mathrm{mM}$ was kept constant. Reaction medium: phosphate of $\mathrm{pH} 6.31$ and $\mu=1.0 \mathrm{M}$. Reaction time: about $5 \mathrm{~min}$ for each of the mixtures at room temperature. Figure S4: Spectrophotometric titration: absorbance at $488 \mathrm{~nm}$ for a series of reaction mixtures of $\left[\mathrm{IrCl}_{6}\right]^{2-}$ with $\mathrm{BH}$ in which $[\mathrm{BH}]_{\text {tot }}$ was changed from 0 to $0.40 \mathrm{mM}$ and $[\mathrm{Ir}(\mathrm{IV})]=0.40 \mathrm{mM}$ was kept constant. Reaction medium: $\left[\mathrm{H}^{+}\right]=0.010 \mathrm{M}$, and $\mu=1.0 \mathrm{M}$. Reaction time: about $2 \mathrm{~h}$ for each of the mixtures at room temperature. Figure S5: Spectrophotometric titration: absorbance at $488 \mathrm{~nm}$ for a series of reaction mixtures of $\left[\mathrm{IrCl}_{6}\right]^{2-}$ with PAH in which $[\mathrm{PAH}]_{\text {tot }}$ was varied from 0 to $0.40 \mathrm{mM}$ and $[\operatorname{Ir}(\mathrm{IV})]=0.40 \mathrm{mM}$ was retained constant. Reaction medium: phosphate buffer of $\mathrm{pH} 6.31$ and $\mu=1.0 \mathrm{M}$. Reaction time: about 30 min for each of the mixtures at room temperature. Figure S6: Spectrophotometric titration: absorbance at $488 \mathrm{~nm}$ for a series of reaction mixtures of $\left[\mathrm{IrCl}_{6}\right]^{2-}$ with PAH in which $[\mathrm{PAH}]_{\text {tot }}$ was varied from 0 to $0.40 \mathrm{mM}$ and $[\operatorname{Ir}(\mathrm{IV})]=0.40 \mathrm{mM}$ was retained constant. Reaction medium: $\left[\mathrm{H}^{+}\right]=0.010 \mathrm{M}$, and $\mu=1.0 \mathrm{M}$. Reaction time: about $2 \mathrm{~h}$ for each of the mixtures at room temperature. Figure S7: (Top): $\mathrm{BH}$ species versus $\mathrm{pH}$ distribution diagram at $25.0^{\circ} \mathrm{C}$ and $\mu=$ $1.0 \mathrm{M}$, which was calculated by use of $\mathrm{p} K_{\mathrm{a} 1}=3.37$ and $\mathrm{p} K_{\mathrm{a} 2}=12.6$ in Table 2. (Bottom): Reactivity versus $\mathrm{pH}$ distribution diagram for the $\mathrm{BH}$ species in the reduction of $\left[\mathrm{IrCl}_{6}\right]^{2-}$; the above $\mathrm{p} K_{\mathrm{a}}$ values and $k_{1}=0.046, k_{2}=597$, and $k_{3}=1.47 \times 10^{8} \mathrm{M}^{-1} \mathrm{~s}^{-1}$ in Table 1 were utilized in the calculations. Species I-III of BH are described in Figure 7. Figure S8: (Top): $\mathrm{PAH}$ species versus $\mathrm{pH}$ distribution diagram at $25.0^{\circ} \mathrm{C}$ and $\mu=1.0 \mathrm{M}$, which was calculated by use of $\mathrm{pK}_{\mathrm{a} 1}=3.24$ and $\mathrm{p} K_{\mathrm{a} 2}=11.7$ in Table 2. (Bottom): Reactivity versus $\mathrm{pH}$ distribution diagram for the PAH species in the reduction of $\left[\operatorname{IrCl}_{6}\right]^{2-}$; the above $\mathrm{p} K_{\mathrm{a}}$ values and $k_{1}=0, k_{2}=157$, and $k_{3}=1.19 \times 10^{6} \mathrm{M}^{-1} \mathrm{~s}^{-1}$ in Table 1 were utilized in the calculations. Species I-III of PAH are described in Figure 7. Figure S9: (Top): Linear plots of $k_{\text {obsd }}$ versus [BH] $]_{\text {tot }}$ in a buffer of $\mathrm{pH}$ 5.10. (Bottom): Eyring plot of the rate-determining step described by $k_{2}$ in the oxidation of $\mathrm{BH}$ by $\left[\mathrm{IrCl}_{6}\right]^{2-}$. Figure S10: (Top): Linear plots of $k_{\mathrm{obsd}}$ versus [PAH $]_{\text {tot }}$ in a buffer of $\mathrm{pH}$ 5.74. (Bottom): Eyring plot of the rate-determining step described by $k_{2}$ in the oxidation of $\mathrm{PAH}$ by $\left[\mathrm{IrCl}_{6}\right]^{2-}$.

Funding: This research was supported financially by the Fundamental Research Funds of Shandong University.

Conflicts of Interest: The author declares no conflict of interest.

\section{References}

1. Majumdar, P.; Pati, A.; Patra, M.; Behera, R.K.; Behera, A.K. Acid hydrazides, potent reagents for synthesis of oxygen-, nitrogen-, and/or sulfur-containing heterocyclic rings. Chem. Rev. 2014, 114, 2942-2977. [CrossRef]

2. Narang, R.; Narasimhan, B.; Sharma, S. A review on biological activities and chemical synthesis of hydrazide derivatives. Curr. Med. Chem. 2012, 19, 569-612. [CrossRef]

3. Rivers, E.C.; Mancera, R.L. New anti-tuberculosis drugs in clinical trials with novel mechanisms of action. Drug Discov. Today 2008, 13, 1090-1098. [CrossRef] [PubMed]

4. Metushi, I.G.; Cai, P.; Zhu, X.; Nakagawa, T.; Uetrecht, J.P. A fresh look at the mechanism of isoniazid-induced hepatotoxicity. Clin. Pharmacol. Therap. 2011, 89, 911-914. [CrossRef] [PubMed] 
5. Wang, P.; Pradhan, K.; Zhong, X.; Mao, X. Isoniazid metabolism and hepatotoxicity. Acta Pharm. Sinica B 2016, 6, 384-392. [CrossRef] [PubMed]

6. Bedia, K.K.; Elçin, O.; Seda, U.; Fatma, K.; Nathaly, S.; Sevim, R.; Dimoglo, A. Synthesis and characterization of novel hydrazide-hydrazones and the study of their structure-antituberculosis activity. Eur. J. Med. Chem. 2006, 41, 1253-1261. [CrossRef] [PubMed]

7. Rollas, S.; Küçükgüzel, S.G. Biological activities of hydrazine derivatives. Molecules 2007, 12, 1910-1939. [CrossRef] [PubMed]

8. Eldehna, W.M.; Fares, M.; Abdel-Aziz, M.M.; Abdel-Aziz, H.A. Design, synthesis and antitubercular activity of certain nicotinic acid hydrazides. Molecules 2015, 20, 8800-8815. [CrossRef] [PubMed]

9. Kumari, D.; Bansal, H. Benzohydrazides: As potential bio-active agents. Pharma Innov. J. 2018, 7, 543-550.

10. Abbas, A.; Ali, B.; Kanwal, K.M.; Khan, K.M.; Iqbal, J.; Ur Rahman, S.; Zaib, S.; Perveen, S. Synthesis and in vitro urease inhibitory activity of benzohydrazide derivatives, in silico and kinetic studies. Bioorg. Chem. 2019, 82, 163-177. [CrossRef]

11. Timmins, G.S.; Deretic, V. Mechanisms of action of isoniazid. Mol. Microb. 2006, 62, 1220-1227. [CrossRef] [PubMed]

12. Wengenack, N.L.; Rusnak, F. Evidence for isoniazid-dependent free radical generation catalyzed by Mycobacterium tuberculosis KatG and the isoniazid-resistant mutant KatG(S315T). Biochemistry 2001, 40, 8990-8996. [CrossRef] [PubMed]

13. Khan, S.R.; Morgan, A.G.M.; Michail, K.; Srivastava, N.; Whittal, R.M.; Aljuhani, N.; Siraki, A.G. Metabolism of isoniazid by neutrophil myeloperoxidase leads to isoniazid-NAD ${ }^{+}$adduct formation: A comparison of the reactivity of isoniazid with its known human metabolites. Biochem. Pharmacol. 2016, 106, 46-55. [CrossRef] [PubMed]

14. Dong, J.; Ren, Y.; Sun, S.; Yang, J.; Nan, C.; Shi, H.; Xu, J.; Duan, J.; Shi, T.; Elding, L.I. Kinetics and mechanism of oxidation of the anti-tubercular prodrug isoniazid and its analog by iridium (IV) as models for biological redox systems. Dalton Trans. 2017, 46, 8377-8386. [CrossRef]

15. Pelizzetti, E.; Mentasti, E.; Baiocchi, C. Kinetics and mechanism of oxidation of quinols by hexachloroiridate(IV) in aqueous acidic perchlorate media. J. Phys. Chem. 1976, 80, 2979-2982. [CrossRef]

16. Pelizzetti, E.; Mentasti, E.; Pramauro, E. Outer-sphere oxidation of ascorbic acid. Inorg. Chem. 1978, 17, 1181-1186. [CrossRef]

17. Stanbury, D.M. Reactions involving the hydrazinium free radical; oxidation of hydrazine by hexachloroiridate. Inorg. Chem. 1984, 23, 2879-2882. [CrossRef]

18. Hubbard, C.D.; Gerhard, A.; van Eldik, R. Electrostriction and counter ion effects in an outer-sphere electron transfer reaction. Kinetics of the reduction of hexachloroiridate(IV) by iodide ion. Dalton Trans. 2001, 1069-1075. [CrossRef]

19. Bhattari, N.; Stanburry, D.M. Oxidation of glutathione by hexachloroiridate(IV), dicyanobis(bipyridine) iron(III), and tetracyano (bipyridine)iron(III). Inorg. Chem. 2012, 51, 13303-13311. [CrossRef]

20. Kim, E.; Winkler, T.E.; Kitchen, C.; Kang, M.; Banis, G.; Bentley, W.E.; Kelly, D.L.; Ghodssi, R.; Payne, G.F. Redox probing for chemical information of oxidative stress. Anal. Chem. 2017, 89, 1583-1592. [CrossRef]

21. Katouaha, H.A.; Al-Fahemia, J.H.; Elghalbana, M.G.; Saada, F.A.; Althagafia, I.A.; El-Metwaly, N.M.; Khedra, A.M. Synthesis of new $\mathrm{Cu}(\mathrm{II})$-benzohydrazide nanometer complexes, spectral, modeling, CT-DNA binding with potential anti-inflammatory and anti-allergic theoretical feature. Mater. Sci. Eng. C: Mater. Biol. Appl. 2019, 96, 740-756. [CrossRef] [PubMed]

22. Jiménez-Pulido, S.B.; Linares-Ordóñez, F.M.; Martínez-Martos, J.M.; Moreno-Carretero, M.N.; Quirós-Olozábal, M.; Ramírez-Expósito, M.J. Metal complexes with the ligand derived from 6-acetyl-1,3,7-trimethyllumazine and benzohydrazide. Molecular structures of two new Co(II) and Rh(III) complexes and analysis of in vitro antitumor activity. J. Inorg. Biochem. 2008, 102, 1677-1683. [CrossRef] [PubMed]

23. Yang, P.; Lim, L.H.; Chuanprasit, P.; Hirao, H.; Zhou, J. Nickel-catalyzed enantioselective reductive amination of ketones with both arylamines and benzhydrazide. Angew. Chem. Int. Ed. 2016, 55, 12083-12087. [CrossRef] [PubMed]

24. Shewale, S.A.; Phadkule, A.N.; Gokavi, G.S. Kinetics and mechanism of oxidation of benzohydrazide by bromate catalyzed by vanadium (IV) in aqueous acidic medium. Int. J. Chem. Kinet. 2008, 40, 151-159. [CrossRef] 
25. Kadam, S.D.; Supale, A.R.; Gokavi, G.S. Kinetics and mechanism of oxidation of benzoic acid hydrazide by bromate catalyzed by octamolybdomanganate(II). Transit. Met. Chem. 2008, 33, 989-994. [CrossRef]

26. Burner, U.; Obinger, C.; Paumann, M.; Furtmuller, P.G.; Kettle, A.J. Transient and steady-state kinetics of the oxidation of substituted benzoic acid hydrazides by myeloperoxidase. J. Biol. Chem. 1999, 274, 9494-9502. [CrossRef] [PubMed]

27. Aitken, S.M.; Quellet, M.; Percival, M.D.; English, A.M. Mechanism of horseradish peroxidase inactivation by benzhydrazide: A critical evaluation of arylhydrazides as peroxidase inhibitors. Biochem. J. 2003, 375, 613-621. [CrossRef]

28. Nan, C.; Dong, J.; Tian, H.; Shi, H.; Shen, S.; Xu, J.; Li, X.; Shi, T. Oxidations of hydrazine and substituted hydrazines by hexachloroiridate (IV) in aqueous solution: Kinetic and mechanistic analyses. J. Mol. Liq. 2018, 256, 489-496. [CrossRef]

29. Wang, J.; Yao, H.; Lu, T.; Dong, J.; Xu, B.; Liu, Y.; Zhou, L.; Liu, C.; Shi, T. Spectroscopic, kinetic, and theoretical analyses of oxidation of dl-ethionine by Pt(IV) anticancer model compounds. Spectrochim. Acta Part A 2019, 223, 117328. [CrossRef]

30. Manoussakis, G.; Haristos, D.; Youri, C. Halogen ring monosubstituted benzoic acid hydrazides as ligands. II. Ultraviolet spectra and $\mathrm{pK}$ determination. Can. J. Chem. 1973, 51, 811-814. [CrossRef]

31. Huo, S.; Shen, S.; Liu, D.; Shi, T. Oxidation of 3, 6-dioxa-1, 8-octanedithiol by platinum(IV) anticancer prodrug and model complex: Kinetic and mechanistic studies. J. Phys. Chem. B 2012, 116, 6522-6528. [CrossRef] [PubMed]

32. Belkheiri, N.; Bouguerne, B.; Bedos-Belval, F.; Duran, H.; Bernis, C.; Salvayre, R.; Nègre-Salvayre, A.; Baltas, M. Synthesis and antioxidant activity evaluation of a syringic hydrazones family. Eur. J. Med. Chem. 2010, 45, 3019-3026. [CrossRef] [PubMed]

33. Yao, H.; Tian, H.; Xu, L.; Xia, Y.; Zhou, L.; Liu, C.; Shi, T. Kinetic and mechanistic analysis of oxidation of 2-furoic hydrazide by hexachloroirradate(IV) in a wide $\mathrm{pH}$ range. Transit. Met. Chem. 2019, 44, 771-777. [CrossRef]

34. Kimura, M.; Yamamoto, M.; Yamabe, S. Kinetics and mechanism of the oxidation of L-ascorbic acid by tris(oxalato)cobaltate(III) and tris(1,10-phenanthroline)iron(III) complexes in aqueous solution. J. Chem. Soc., Dalton Trans. 1982, 423-427. [CrossRef]

Sample Availability: Samples of the compounds $\mathrm{BH}, \mathrm{PAH}$, and $\mathrm{Na}_{2} \mathrm{IrCl}_{6} \cdot 6 \mathrm{H}_{2} \mathrm{O}$ are available from the author.

(C) 2020 by the author. Licensee MDPI, Basel, Switzerland. This article is an open access article distributed under the terms and conditions of the Creative Commons Attribution (CC BY) license (http://creativecommons.org/licenses/by/4.0/). 